\title{
Novel Salmonella spp. Diagnostic Markers Based on the gyrB Gene and its Application on Food and Environmentally-Derived Water Samples
}

\author{
Audrey Leo, Wei Wei Tow, Julian Hill, Jeffrey Robert English and Rebecca Ford
}

\author{
Melbourne School of Land and Environment, The University of Melbourne, Victoria, 3010, Australia
}

\begin{abstract}
Salmonellosis is a major cause of gastrointestinal infection that generally occurs through the ingestion of fecally contaminated food or water. Molecular markers based on the gyrase B (gyrB) gene sequence, a Type II DNA topoisomerase subunit enzyme family member, were developed to specifically and sensitively discriminate Salmonella spp. from closely related and collocated microorganisms in a water environment. For this, gyrB gene sequences of Salmonella spp., E. coli, Yersinia enterocolitica, Klebsiella pneumoniae and Shigella spp. were aligned and found up to $88 \%$ similar. Markers amplified from primers specific to the Salmonella gyrB sequences were conserved across $13 S$. enterica and one $S$. bongori serovar, and were able to detect approximately one $S$. Enteritidis genome. These were more specific and sensitive than the international standard invA gene-based Salmonella marker. The gyrB markers detected 725 Salmonella genomes in $100 \mathrm{~mL}$ of seeded environmental water sediment sample and 72 Salmonella genomes in $300 \mathrm{~g}$ of seeded minced samples. Successful detection of Salmonella in non-inoculated minced samples was also achieved, with higher sensitivity than the invA markers. These makers should be useful in future risk analyses and standards setting for Salmonella presence in food, and water used for irrigation and recreational purposes.
\end{abstract}

Keywords: gyrB gene, pathogen detection, PCR, Salmonella, water, food.

\section{INTRODUCTION}

The Salmonella enterica family comprises a diverse range of Salmonella spp. including approximately 2557 known serotypes that may cause zoonotic diseases in humans and animals [1]. Salmonellae often associated with faecally contaminated food or water is responsible for approximately 600 deaths per annum in the USA, indicating that the disease is a major health concern [2]. Approximately 1200 cases of Salmonellosis are reported per annum in Australia [3]. Although most of the reported cases were foodborne, less than $1 \%$ of gastroenteritis outbreaks in Australia are classified as waterborne or suspected waterborne via contaminated drinking and recreational water [4]. More than half of the waterborne-related outbreaks are caused by Salmonella spp. and the remaining are caused by other foodborne and waterborne parasites, viruses and bacteria [5].

Rapid, sensitive and specific methods are required to identify and monitor Salmonella and safeguard the public from foodborne and waterborne-related outbreaks. For this, molecular techniques offer advantages of speed and accuracy over the traditional culture, microscopy or standard biochemical techniques [6-8]. These methods also overcome issues with under-representative detection of viable but

*Address correspondence to this author at the Melbourne School of Land and Environment, The University of Melbourne, Victoria, 3010, Australia; Tel: (+613) 8344 9753; Fax: (+613) 8344 5037; E-mail: rebeccaf@unimelb.edu.au non-culturable cells (VBNC) [9-11]. In particular, sequence-specific polymerase chain reaction (PCR)based methods are increasingly being used for fast, sensitive and accurate detection and diagnosis of pathogen contaminants $[6,12]$.

Several gene sequences have been targeted as putative diagnostic markers to specifically detect Salmonella spp. including; the oriC, ompC and invA genes [13-15]. However, primers designed to amplify oriC and ompC sequences produced non-Salmonellaspecific amplicons from related organisms such as Citrobacter spp., Yersinia enterocolitica, Klesbsiella oxytocanm, Proteus vulgaris and Hafina alvei [16]. The $\operatorname{inv} A$ gene is widely used as an international standard to detect Salmonella in both food [17] and environmental samples [18, 19]. A PCR assay based on the invA gene was able to detect as few as 10 copies of purified Salmonella genomic DNA with the inclusion of 300 copies of an Internal Amplification Control (IAC) [16]. The sensitivity of the same invA gene marker was also observed to be comparable to that developed by Malorny et al. 2003 [16] when assessing one millilitre of Salmonella-seeded homogenate food sample [17]. However, it was also noted that PCR products of the same approximate size were also amplified from several E. coli strains [16].

As an alternative to previously targeted sequences, the gyrB gene sequence may be sufficiently polymorphic to differentiate Salmonella spp., in particular $S$. enterica, from closely related 
microorganisms such as E. coli and Shigella spp. [2022]. The gyrB gene is a member of the Type II DNA topoisomerase subunit enzyme family [23], which catalyse breakage and reformation of double stranded DNA [24]. Although present in all organisms, the gyrB gene sequence differs among microorganisms at the sub-species level, reportedly due to greater evolutionary divergence in comparison to ribosomal gene sequences [20, 25-27]. For example, E. coli and Shigella sonnei were $0.2 \%$ different within the $16 \mathrm{~S}$ rRNA sequence but $1.9 \%$ different within the $g y r B$ sequence [20, 24, 28]. The average difference in gyrB sequence between Salmonella spp. and E. coli and Shigella spp. is $9.4 \%$ and $9.3 \%$, respectively [20] and from other related genera such as Yersinia and Klebsiella is $22.9 \%$ and $10.8 \%$, respectively [20].

Therefore, the aims of this study were to: (1) develop a novel gyrB gene PCR-based marker to differentiate Salmonella spp. from closely related microorganisms that are commonly found in environmental water and food samples; (2) determine the ability of the $g y r B$ marker to detect Salmonella spp. in seeded chicken mince and environmentally-derived water sediment samples; and (3) compare the specificity and sensitivity of the gyrB marker with the inv $A$ marker, currently used as the international Salmonella diagnostic gene standard.

\section{MATERIALS AND METHODS}

\section{Bacterial Culture Strains and Genomic DNA Isolation}

Clinical isolates of 13 different serovars of Salmonella enterica, one serovar of Salmonella bongori, six Escherichia coli strains, two Shigella spp. strains and an isolate each of Campylobacter jejuni and Bacteroides fragilis were obtained from either the Department of Microbiology and Immunology, Microbial Diagnostic Unit of The University of Melbourne, Victoria, Australia; Micromon at Monash University,

Table 1: Clinical Bacterial Strains Included for Assessment of Specificity of Novel gyrB Markers

\begin{tabular}{|c|c|c|}
\hline Microorganism & Strain/Serovar & Source \\
\hline \multirow[t]{6}{*}{ Escherichia coli } & ATCC 259922 & MDU \\
\hline & OIII:K58 & Micromon \\
\hline & 1848 & Micromon \\
\hline & DH5:2 & Micromon \\
\hline & $\mathrm{K} 12$ & Micromon \\
\hline & TGI & Micromon \\
\hline \multirow[t]{2}{*}{ Shigella } & flexneri & Micromon \\
\hline & boydii & Micromon \\
\hline Campylobacter jejuni & NCTC 11392 & MDU \\
\hline Bacteroides & Fragilis NCTC 9343 & MDU \\
\hline \multirow[t]{14}{*}{ Salmonella enterica } & Enteritidis & MDU \\
\hline & Enteritidis & IMVS \\
\hline & Typhimurium & IMVS \\
\hline & Adelaide & IMVS \\
\hline & Dublin & IMVS \\
\hline & Heidelberg & IMVS \\
\hline & Paratyphi B var Java & IMVS \\
\hline & Newport & IMVS \\
\hline & Saintpaul & IMVS \\
\hline & Infantis & IMVS \\
\hline & Derby & IMVS \\
\hline & Brandenburg & IMVS \\
\hline & Bredeney & IMVS \\
\hline & Illb $61: i: z_{53}$ & IMVS \\
\hline Salmonella & Bongori $\left(66: z_{65}:-\right)$ & IMVS \\
\hline
\end{tabular}

Where: MDU = Microbial Diagnostic Unit, The University of Melbourne, Victoria, Australia; Micromon = Monash University, Victoria, Australia; and IMVS = Institute of Medical and Veterinary Science, Adelaide, South Australia, Australia. 
Victoria, Australia or the Institute of Medical and Veterinary Science, Adelaide, South Australia, Australia (Table 1).

Salmonella spp., E. coli and Shigella spp. were grown on nutrient agar (Oxoid, Australia) at $37^{\circ} \mathrm{C}$ for 24 h. Single colonies were grown on XLD selective medium and MacConkey agar (Oxoid, Australia). After identification using Microbact ${ }^{\mathrm{TM}}$ 24E (Oxoid, Australia), a single colony was picked and inoculated into $10 \mathrm{~mL}$ of nutrient broth and grown at $37{ }^{\circ} \mathrm{C}$ for $24 \mathrm{~h}$. Campylobacter jejuni and Bacteriodes fragilis were anaerobically grown on Campylobacter selective media (Oxoid, Australia) at $47^{\circ} \mathrm{C}$ and Bacteroides Bile Esculin Agar (Oxoid, Australia) at $37{ }^{\circ} \mathrm{C}$ for $48 \mathrm{~h}$, respectively. Single colonies were resuspended directly into $1.5 \mathrm{~mL}$ of nutrient broth. The inoculated nutrient broth was then centrifuged at $14,000 \mathrm{~g}$ for 2 min to obtain a cell pellet. The supernatant was discarded and total genomic (g)DNA was extracted with the Ultraclean Microbial DNA Isolation Kit (MoBio, Australia). DNA quality and quantity were assessed by agarose gel electrophoresis.

\section{A Novel gyrB Marker for Salmonella spp.: Specificity and Sensitivity}

Initially, a set of 81 gyrB sequences ( 1200 bp) were accessed from the GenBank databases (www.ncbi.nim.nih.gov) comprising 38 strains of E. coli, 15 strains of Shigella flexneri, 12 strains of Shigella sonnei, 1 strain of Klebsiella pneumonia, 1 strain of Yersinia enterocolitica and 14 strains of Salmonella spp. The strain-specific sequences from within each bacterial species were then aligned using ClustalW (www.ebi.ac.uk/Tools/ clustalw) to provide a consensus gyrB sequence for each species. Subsequently, the species consensus gyrB sequences were aligned to identify Salmonella-specific sequence suitable for development of novel and discriminatory PCR primers. The Salmonella-specific primer sequences were 100\% homologous to all of the Salmonella strains assessed.

The gyrB gene primers were assessed in $25 \mu \mathrm{L}$ PCR reactions comprising PCR buffer (Scientifix, Australia), $1.5 \mathrm{mM} \mathrm{MgCl}_{2}$ (Scientifix, Australia), $200 \mu \mathrm{M}$ of each dNTP (Scientifix, Australia), $0.4 \mu \mathrm{M}$ of each primer (Sigma Genosys, Australia), 1.25 units of Taq Polymerase (Scientifix, Australia) and $100 \mathrm{ng}$ of gDNA (Table 1). The thermal cycling conditions were; initial denaturation at $95^{\circ} \mathrm{C}$ for $5 \mathrm{~min}$, followed by 30 cycles of $96{ }^{\circ} \mathrm{C}$ for $1 \mathrm{~min}, 63^{\circ} \mathrm{C}$ for $1 \mathrm{~min}$ and $72{ }^{\circ} \mathrm{C}$ for $1 \mathrm{~min}$ with a final extension at $72{ }^{\circ} \mathrm{C}$ for $1 \mathrm{~min}$. The $g y r B$ marker was compared for specificity against the $\operatorname{inv} A$ gene marker $[14,16]$ to discriminate the Salmonella from the non-Salmonella species strains (Table 1). The PCR reaction and its thermal cycling conditions for the amplification of the invA marker, using the primer pair $139 \mathrm{~F}$ and $141 \mathrm{R}$, were as previously described $[14,16]$. Markers were visualised on agarose gel, excised, purified using Freeze N' Squeeze DNA Gel Extraction Kit (Bio-Rad, Australia), cycle sequenced by Macrogen, Korea (www.macrogen.com) and BLASTN searched for similar sequences against the NCBI GenBank databases.

Sensitivity of the $g y r B$ marker was assessed using a 10 -fold dilution series of $10 \mathrm{ng}, 1 \mathrm{ng}, 100 \mathrm{pg}, 10 \mathrm{pg}, 1$ $\mathrm{pg}, 100 \mathrm{fg}$ or $10 \mathrm{fg}$ of $S$. enterica serovar Enteritidis gDNA extracted from pure culture. Traditional PCR conditions were as previously described and genome copy number was calculated based on the molecular weight of $S$. enterica serovar Enteritidis ( 5.0 fg/genome; www.sanger.ac.uk/Projects/Salmonella/) where genome copy number $=$ (concentration of sample per $\mu \mathrm{L} /$ weight of 1 genome in $\mathrm{ng}) \mathrm{X}$ gene copies per genome. In general, $2.5 \mathrm{pg}$ Salmonella genomic DNA is approximately equivalent to 500 genomes [29].

Quantitative Real-Time (qRT) PCR assays were performed on an IQ5 thermocycler (Bio-Rad, Australia) with the Salmonella-specific gyrB primers in $25 \mu \mathrm{L}$ volumes comprising 10 -fold dilution of pure $S$. enterica serovar Enteritidis gDNA (14.5 $\mathrm{ng}$ to $14.5 \mathrm{fg}$ ) and $S$. enterica serovar Typhimurium (52.1 ng to $52.1 \mathrm{fg}$ ), IQ SYBR Green Supermix (Bio-Rad, Australia) and 0.4 $\mu \mathrm{M}$ of each gyrB primer (Sigma Genosys, Australia). Cycle conditions were: Initial denaturation at $95^{\circ} \mathrm{C}$ for $1 \mathrm{~min} ; 40$ cycles of $95^{\circ} \mathrm{C}$ for $10 \mathrm{~s}, 65^{\circ} \mathrm{C}$ for $15 \mathrm{~s}, 72^{\circ} \mathrm{C}$ for $30 \mathrm{~s}$ and $83^{\circ} \mathrm{C}$ for $10 \mathrm{~s}$ (fluorescence reading), followed by melt curve analysis from 65 to $95{ }^{\circ} \mathrm{C}$ with $0.5^{\circ} \mathrm{C} / 10 \mathrm{~s}$ increments. All reactions were performed in duplicate and mean $C_{t}$ values were used to calculate the number of gene copies utilising a threshold line of 75. The number of Salmonella spp. genome copies in correlation to the DNA concentration (ng/ $\mu \mathrm{L}$ ) was calculated using the regression line produced by the standard curve followed by the calculation described above, based on the molecular weight of the Salmonella genome. The mathematical model of the regression line was equivalent to $Y=m X+c$, where $Y$ is the $C_{t}$ value, $\mathrm{m}$ is the slope, $\mathrm{X}$ is the log of the gene copy number and $c$ is the interception value when $Y=0$. PCR efficiencies were calculated from the standard 
curves using the following equation: PCR efficiency $=$ $\left[10^{(-1 / \mathrm{m})}-1\right][30]$.

\section{Detection of Salmonella spp. in Environmentally- Derived Water Samples}

Water samples $(10 \mathrm{~L})$ were collected from a large rural water catchment system in SE Australia between August 2006 and October 2007 [31]. After collection and transportation to the laboratory, $100 \mathrm{~mL}$ of each sample was immediately filtered through a $0.45 \mu \mathrm{M}$ pore size filter membrane (Millipore, Australia) using a vacuum pump. The collected particulate biomass was detached from the filter membrane using a sterile pipette tip and resuspended in $1 \mathrm{~mL}$ of sterile ultrapure water. The biomass was then harvested by centrifugation at $18,000 \mathrm{~g}$ for $2.5 \mathrm{~min}$. The supernatant was discarded and gDNA from the collected pellet was extracted using the Ultraclean ${ }^{\mathrm{TM}}$ Soil DNA Isolation Kit (MoBio, Australia). The gDNA was resuspended in 20 $\mu \mathrm{L}$ of sterile water and checked for integrity via agarose gel electrophoresis.

In order to demonstrate that the gyrB marker was amplifiable from an environmentally-derived water sample background, gDNA from sediment samples previously identified as negative for Salmonella using traditional microbiology techniques [32] were seeded with $S$. Enteritidis gDNA. For this, total gDNA from sediment samples was resuspended in $100 \mu \mathrm{L}$ of sterile $\mathrm{H}_{2} \mathrm{O}$ and $S$. Enteritidis gDNA was added to

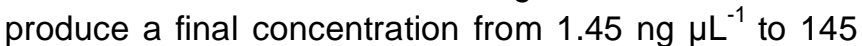
fg $\mu \mathrm{L}^{-1}$. Subsequently, $1 \mu \mathrm{L}$ of each concentration was used as template in the same qRT-PCR conditions as previously described with the SalEF3/R3 primers to quantify production of the $205 \mathrm{bp}$ marker.

To validate that the $g y r B$ marker was able to amplify Salmonella from a naturally infected sample, an environmentally-derived water sample (Site 020 March 2007) identified as positive for Salmonella using traditional microbiology techniques [32], was used. For this, the previously described traditional PCR conditions were used together with water sedimentderived total gDNA template amounts ranging from 100 $\mathrm{ng}$ to $400 \mathrm{ng}$. The PCR product was visualised on agarose gel, sequenced as previously described and compared with sequences on the GenBank databases to confirm the diagnosis of Salmonella spp.

\section{Detection of Salmonella spp. in Minced Chicken}

Applicability of the gyrB markers to detect Salmonella spp. in food-derived sample was tested on both artificially and naturally contaminated chicken mince. Both types of experiments were done in triplicate to ensure reproducible and reliable results. Twelve samples of 300 grams of chicken mince were purchased from six different local markets and one major supermarket chain in Australia. Samples were de-identified upon arrival and stored at $4{ }^{\circ} \mathrm{C}$ until further processing.

For artificially inoculated samples, 50 grams of the minced samples derived from the local markets were autoclaved and then added with $450 \mathrm{~mL}$ of $0.1 \%$ buffered peptone water (BPW) (Oxoid, Australia) before being homogenized in a stomacher for $2 \mathrm{~min}$. The homogenized sample was then artificially inoculated with $100 \mu \mathrm{L}$ of serial diluted BPW containing 10-100, 100-1000, 1000-10000 CFU of S. Typhimurium which was previously enumerated for its CFU count on nutrient agar. In relation to food borne illnesses and the ease of comparison between traditional microbiological and molecular based techniques, CFU counts instead of cell numbers were used to inoculate minced chicken samples. Contaminated samples were then preenriched by incubating them at $37{ }^{\circ} \mathrm{C}$ for 18 hours without shaking as optimised by Trevanich et al. 2010 [33]. One $\mathrm{mL}$ of each pre-enriched samples containing serially diluted CFU counts was then taken for viable count and gDNA extraction. Genomic DNA was extracted by thermal cell lysis using Chelex100 (Biorad, Australia) according to Malorny et al. 2003 [16].

For detection in naturally contaminated samples, 50 $\mathrm{g}$ of minced chicken sample from a local market or supermarket was added to $450 \mathrm{~mL}$ of BPW and directly homogenized, pre-enriched and extracted as previously described. Extracted gDNA was then amplified with qRT-PCR according to the method described previously. The quantity of the PCR products obtained was plotted against the standard curve to estimate the amount of Salmonella contamination in the samples.

For a comparison on how sensitive the gyrB marker is with the existing universal gene marker, $\operatorname{inv} A$, detection of Salmonella in minced samples with invA marker was also done. Four $\mu \mathrm{L}$ of the extracted gDNA from artificially inoculated and naturally infected samples was used as a template with the addition of IQ SYBR Green Supermix (Bio-Rad, Australia) and 0.2 $\mu \mathrm{M}$ of each invA primer (Sigma Genosys, Australia) in a 25 reaction. Cycle conditions were: Initial denaturation at $95{ }^{\circ} \mathrm{C}$ for $1 \mathrm{~min} ; 40$ cycles of $95{ }^{\circ} \mathrm{C}$ for $10 \mathrm{~s}, 65^{\circ} \mathrm{C}$ for $15 \mathrm{~s}, 72{ }^{\circ} \mathrm{C}$ for $30 \mathrm{~s}$ and $83^{\circ} \mathrm{C}$ for $10 \mathrm{~s}$ 
(fluorescence reading), followed by melt curve analysis from 65 to $95^{\circ} \mathrm{C}$ with $0.5^{\circ} \mathrm{C} / 10 \mathrm{~s}$ increments.

\section{RESULTS}

\section{A Novel Salmonella spp. gyrB Gene Marker: Specificity and Sensitivity}

Alignment of the consensus gyrB sequences revealed a sequence identity of $86 \%$ between Salmonella spp. and E. coli, of $78 \%$ between Salmonella and Yersinia enterocolitica and of $88 \%$ equally between Salmonella spp. and Shigella spp. and Klebsiella pneumoniae. The following primer sites were identified as unique to Salmonella spp.: SalEF1 5'ACGCTCTGTCGCAAAAACTG-3' at position 56 to 76 and SalER1 5'-GTGACGGCCAGGGGTGCC-3' at position 138 to 156 . Two alternative unique primer sites were also identified: SalEF3 5'-CGTGGGCGTCTC GGTAGTY-3' at position 35 to 54 and SalER3 5'CTCATATTCAAATTCAGTGACG-3' at position 218 to 241 within S. enterica strain SSM1592 gyrB (accession DQ386877).

When assessed for specificity against isolates in Table 1, the SalEF1/R1 and SalEF3/R3 primers amplified a clear and reproducible $100 \mathrm{bp}$ and $205 \mathrm{bp}$ products, respectively from only the $S$. enterica and $S$. bongori samples. Also, the gyrB marker sequences amplified among all of the assessed $S$. enterica and $S$. bongori serovars were $100 \%$ homologous. In comparison, following the described PCR conditions [28], the 284 bp invA marker was amplified from E. coli ATCC 259922, C. jejuni NCTC 11392 and Bacteroides fragilis NTCC 9343 as well as the Salmonella spp.

Following traditional PCR with the SalEF1/R1 and SalEF3/R3 primers, the $100 \mathrm{bp}$ and $205 \mathrm{bp}$ gyrB markers were visualised on agarose gel after amplification from just $10 \mathrm{pg}$ of pure $S$. Enteritidis MDU gDNA (Table 1). This was calculated to be representative of 2000 genomes given an approximate molecular weight of $S$. enterica at $5.0 \mathrm{fg} / \mathrm{genome}$ and an assumption of one gyrB gene per genome.

The detection sensitivity of gyrB gene marker, SalEF3/R3 was tested with quantitative RT-PCR using serially diluted gDNA from the same $S$. Enteritidis and $S$. Typhimurium cultures. A single peak was observed in the post-amplification dissociation curves at $85.50^{\circ} \mathrm{C}$. The standard curve for $S$. Enteritidis and $S$. Typhimurium using SalEF3/R3 primers produced $R^{2}$ values of 0.996 and 0.997 with slopes of -2.886 and 3.0768 , respectively. Both reactions achieved an amplification efficiency of $\geq 95 \%$ with detection sensitivities of $145 \mathrm{fg}$ for pure $S$. Enteritidis and $521 \mathrm{fg}$ DNA for $S$. Typhimurium. These equated to the detection of approximately six $S$. Enteritidis and one $S$. Typhimurium genomes under the same assumptions previously stated (Tables 2 and 3 ).

Table 2: Detection and Quantification of Serial Diluted gDNA Salmonella enterica Serovar Enteritidis with gyrB Marker

\begin{tabular}{|c|c|c|}
\hline $\begin{array}{c}\text { S. Enteritidis gDNA } \\
(\mathbf{n g} / \boldsymbol{\mu L})\end{array}$ & Mean $\boldsymbol{C}_{\boldsymbol{t}}$ & $\begin{array}{c}\text { Genome copy } \\
\text { numbers (per assay) }\end{array}$ \\
\hline \hline 14.5 & 20.57 & $7.41 \times 10^{5}$ \\
\hline $14.5 \times 10^{-1}$ & 23.63 & $6.45 \times 10^{4}$ \\
\hline $14.5 \times 10^{-2}$ & 26.12 & $8.85 \times 10^{3}$ \\
\hline $14.5 \times 10^{-3}$ & 28.53 & $1.29 \times 10^{3}$ \\
\hline $14.5 \times 10^{-4}$ & 32.05 & $7.80 \times 10^{1}$ \\
\hline $14.5 \times 10^{-5}$ & 35.24 & $6.13 \times 10^{0}$ \\
\hline
\end{tabular}

Table 3: Detection and Quantification of Serial Diluted gDNA Salmonella enterica Serovar Typhimurium with gyrB Marker

\begin{tabular}{|c|c|c|}
\hline $\begin{array}{c}\text { S. Typhimurium } \\
\text { gDNA }(\mathrm{ng} / \mu \mathrm{L})\end{array}$ & Mean $\boldsymbol{C}_{\boldsymbol{t}} \pm \mathrm{SE}$ & $\begin{array}{c}\text { Genome copy } \\
\text { numbers (per assay) }\end{array}$ \\
\hline \hline $52.1 \times 10^{-1}$ & $14.10 \pm 0.08$ & $8.3017 \times 10^{4}$ \\
\hline $52.1 \times 10^{-2}$ & $16.87 \pm 0.05$ & $1.05 \times 10^{4}$ \\
\hline $52.1 \times 10^{-3}$ & $19.92 \pm 0.02$ & $1.07 \times 10^{3}$ \\
\hline $52.1 \times 10^{-4}$ & $23.18 \pm 0.08$ & $9.3 \times 10^{1}$ \\
\hline $52.1 \times 10^{-5}$ & $26.63 \pm 0.06$ & $7 \times 10^{0}$ \\
\hline $52.1 \times 10^{-6}$ & $29.82 \pm 1.38$ & $1 \times 10^{0}$ \\
\hline
\end{tabular}

\section{Ability of gyrB Marker to Detect Salmonella spp. in Environmentally-Derived Water Samples and Chicken Mince}

Following seeding of water-derived sediment samples, the minimum amount of pure $S$. Enteritidis gDNA that was detected using qRT-PCR was $145 \mathrm{fg}$ using the SalEF3/R3 primers. This equated to 725 genomes (per $100 \mathrm{~mL}$ of sample).

A clear and reproducible 205 bp marker was amplified from $400 \mathrm{ng}$ (approximately $2.0 \times 10^{-8}$ genomes per $100 \mathrm{~mL}$ of non-seeded sediment-derived gDNA), previously shown to contain Salmonella, using the SalEF3/R3 primer pair. The 205 bp marker sequence was highly homologous to published $g y r B$ sequence from S. enterica and S. bongori (e.g. $99 \%$ similar to AM933173). 
Table 4: Detection of Salmonella enterica Serovar Typhimurium from Artificially Contaminated Chicken Mince with gyrB Marker

\begin{tabular}{|c|c|c|}
\hline Amount of $S$. Typhimurium (CFU/mL) seeded into samples & Mean $\boldsymbol{C}_{\boldsymbol{t}} \pm \mathrm{SE}$ & Genome copy numbers (per 300g) \\
\hline \hline Negative control (Blank) & $35.67 \pm 0.37$ & 0 \\
\hline $1.0 \times 10^{-6}$ & $17.87 \pm 0.42$ & $6.24 \times 10^{6}$ \\
\hline $1.0 \times 10^{-5}$ & $21.86 \pm 0.18$ & $6.96 \times 10^{3}$ \\
\hline $1.0 \times 10^{-4}$ & $24.79 \pm 0.21$ & $3.55 \times 10^{2}$ \\
\hline $1.0 \times 10^{-3}$ & $28.77 \pm 0.21$ & $7.2 \times 10^{1}$ \\
\hline $1.0 \times 10^{-2}$ & $30.90 \pm 0.93$ & \\
\hline
\end{tabular}

The SalEF3/R3 marker was also successful in amplifying a reproducible and clear $205 \mathrm{bp}$ band from Salmonella in the presence of background microflora and inhibitors in minced chicken. In artificially inoculated samples, gyrB marker was able to consistently amplify at least $10^{2} \mathrm{CFU} / \mathrm{mL}$ of $S$. Typhimurium (Table 4). When the average $C_{t}$ value of the $10^{2} \mathrm{CFU} / \mathrm{mL}$ of Salmonella in the seeded sample was compared to the standard curve of the pure gDNA of $S$. Typhimurium, the detection limit of $10^{2} \mathrm{CFU} / \mathrm{mL}$ equated to approximately 72 genomes per 300 grams of sample.

In non-seeded chicken mince, Salmonella was detected from three of the six samples derived from six different local markets. The amplification results were reproducible for each replication with $S D$ values ranging from 0.07 to 0.67 . The average $C_{t}$ values obtained for the three samples were 29.94, 26.16 and 25.99. When the $C_{t}$ values of the unknown samples were compared against the $S$. Typhimurium standard curve, approximately 148, 2503 and 2843 genomes of Salmonella per 300 gram of samples were detected, respectively. Amplification of Salmonella in non-seeded food samples indicated that the marker is robust enough to detect Salmonella in the presence of background microflora and other inhibitory food components.
Amplification of Salmonella spp. in Pure Culture and Chicken Mince with invA Marker

Quantitative RT-PCR using serial diluted gDNA from the same $S$. Typhimurium culture with the $\operatorname{inv} A$ primers produced a single peak and an $R^{2}$ value of 0.994 with a slope of -3.373 . The reaction achieved an amplification efficiency of $107.5 \%$ with detection sensitivity of $499.2 \mathrm{fg}$ DNA for $S$. Typhimurium. This equated to the detection of approximately five $S$. Typhimurium (Table 5) genomes.

The InvA gene was able to amplify Salmonella from artificially inoculated chicken mince but none of the naturally infected samples. The threshold detection sensitivity of the invA in artificially inoculated samples was a minimum of $10^{3} \mathrm{CFU} / \mathrm{mL}$ of $S$. Typhimurium (Table 6). This equated to the detection of 832 genomes per 300 grams of sample.

\section{DISCUSSION}

Ubiquitous to the environment, Salmonella is known as one of the leading causes of food poisoning, accounting for one of the highest morbidity and mortality rates of foodborne diseases worldwide [34]. More than $50 \%$ of outbreaks caused by bacteria are attributed to Salmonella with $S$. Enteritidis and $S$.

Table 5: Detection and Quantification of Serial Diluted gDNA Salmonella enterica Serovar Typhimurium with invA Marker

\begin{tabular}{|c|c|c|}
\hline S. Typhimurium gDNA $(\mathrm{ng} / \mu \mathrm{L})$ & Mean $\boldsymbol{C}_{\boldsymbol{t}} \pm \mathrm{SE}$ & Genome copy numbers (per assay) \\
\hline \hline $49.9 \times 10^{-1}$ & $13.25 \pm 0.47$ & $6.85 \times 10^{5}$ \\
\hline $49.9 \times 10^{-2}$ & $16.36 \pm 0.18$ & $8.17 \times 10^{4}$ \\
\hline $49.9 \times 10^{-3}$ & $19.83 \pm 0.20$ & $7.67 \times 10^{3}$ \\
\hline $49.9 \times 10^{-4}$ & $22.93 \pm 0.19$ & $9.24 \times 10^{2}$ \\
\hline $49.9 \times 10^{-5}$ & $25.74 \pm 0.11$ & $1.35 \times 10^{2}$ \\
\hline $49.9 \times 10^{-6}$ & $30.61 \pm 0.06$ & $5 \times 10^{0}$ \\
\hline
\end{tabular}


Table 6: Detection of Salmonella enterica serovar Typhimurium from Artificially Contaminated Chicken Mince with invA Marker

\begin{tabular}{|c|c|c|}
\hline Amount of $\boldsymbol{S}$. Typhimurium (CFU/mL) seeded into samples & Mean $\boldsymbol{C}_{\boldsymbol{t}} \mathbf{\mathrm { SE }}$ & Genome copy numbers (per 300g) \\
\hline \hline Negative control (Blank) & $35.59 \pm 1.37$ & 0 \\
\hline $1.0 \times 10^{-6}$ & $17.19 \pm 0.04$ & $2.32 \times 10^{6}$ \\
\hline $1.0 \times 10^{-5}$ & $22.57 \pm 0.40$ & $5.89 \times 10^{4}$ \\
\hline $1.0 \times 10^{-4}$ & $25.45 \pm 0.20$ & $8.25 \times 10^{3}$ \\
\hline $1.0 \times 10^{-3}$ & $28.81 \pm 0.63$ & $8.32 \times 10^{2}$ \\
\hline
\end{tabular}

Typhimurium being reported as the two most prevalent of the known 2500 serotypes [35, 36]. Due to high economic and social impacts caused by salmonellosis, rapid detection and diagnostic methods are imperative to prevent, control and limit infections. The aim of this research was to develop a rapid test for the detection of Salmonella on environmentally derived water samples and food samples using traditional and realtime PCR assay, targeting the gyrB gene.

National standards for acceptable Salmonella dosages are lacking in Australia. There are international and national standards for 'drinking' water quality, however Australian standards governing 'environmental' water quality do not exist. This includes water used to irrigate food crops and for recreational use. Meanwhile, there is a zero tolerance level of Salmonella dosage in food based on the 1995 Microbiological Reference Criteria for Food, irrespective of strain [37]. The lack of clarity around microbiological standards is likely due to direct detection and enumeration difficulty in water and food products. This is particularly true for Salmonella spp. which may be inaccurately predicated through fecal coliform or E. coli. detection [38]. Also, no specific media is able to grow Salmonella in isolation, without cultivating other microorganisms such as Proteus spp. or even Pseudomonas spp. [39, 40].

To enable rapid and specific Salmonella spp. detection and direct enumeration from water and food samples, quantifiable gyrB gene diagnostic markers were developed. These discriminated Salmonella spp. from other water and food-borne fecal contaminants such as Bacteroides fragilis and other closely related microorganisms, such as E. coli and Shigella. They successfully amplified 13 different $S$. enterica serovars as well as $S$. bongori, reflecting a high conservation of the gyrB gene within the Salmonella genus. Conversely, a suitable rate of evolution was detected within the gyrB sequence to discriminate between genera [20]. In comparison, the invA marker [14] is not specific to Salmonella and amplifies from E. coli [16], Klebsiella pneumoniae, Pseudomonas aeruginosa and Citrobacter freundii [14, 41], and Campylobacter jejuni and Bacteroides fragilis (this study). Crossamplification with closely related species with a high probable presence in a water environment substantially reduces the diagnostic power of the marker.

Quantitative amplification of the 205 bp gyrB marker detected $10 \mathrm{pg}$ (2,000 genomes) of extracted $S$. enterica gDNA while the detection limit of the invA gene marker was reported to be 300 cells (genomes); based on the detection of $27 \mathrm{pg}$ of extracted gDNA [14]. However, re-calculation of the invA genome copy number (based on $27 \mathrm{pg}$ and the equation described previously) indicated a detection threshold of 5,000 genomes rather than the claimed 300 . In seeded water samples, the 205 bp gyrB marker detected 725 genomes per $100 \mathrm{ml}$ of seeded environmentallyderived water sample. In non-seeded and naturally infected water samples, a minimum of $400 \mathrm{ng}(2.0 \mathrm{x}$ $10^{-8}$ genomes per $100 \mathrm{ml}$ ) of sediment-derived total gDNA was required for Salmonella spp. detection. In chicken mince samples, the gyrB marker was also proven to be more sensitive, able to detect as few as 72 genomes in artificially contaminated samples in comparison to the threshold of 832 genomes detected with the invA marker.

Immunoassay based commercial kits such as Tecra Unique $^{\mathrm{TM}}$ (Tecra, Australia), VIDAS Salmonella assay (bioMérieux, France) and 1-2 Test for Salmonella (Biocontrol Systems, USA) are used to generate presumptive positive and negative tests for Salmonella within two days [34]. Whilst highly sensitive, reportedly detecting as little as one to five CFU per $25 \mathrm{~g}$ of sample, results must be confirmed with standard culturing methods [42]. Sensitivity of the kits is also affected by background flora potentially resulting in false negatives [43, 44]. Accordingly, molecular 
markers may be more reliable, although also suffer from reduced sensitivity related to PCR efficiency. This may result from competition for primer binding sites within a diverse microflora. Although optimisation of PCR conditions, including annealing temperature, was conducted [45], primer specificity may influence the reaction since $g y r B$ sequences from other microbes potentially present in the same environment were unavailable for direct comparison to the Salmonella gyrB sequence. Also, the efficiency of the PCR assay may have been affected by the DNA extraction method, which may not have removed all PCR inhibitors such as humic substances, complex carbohydrates or other organic compounds such as blood [40, 46, 47]. The Ultraclean $^{\mathrm{TM}}$ MoBio Soil DNA extraction kit (MoBio, Australia) according to Behets et al. 2007 [48] and Klerks et al. 2006 [49], is an efficient water extraction technique for subsequent PCR amplification. However, further DNA purification methods should be investigated. PCR sensitivity may also be improved by including 30 to 300 copies of an Internal Amplification Control in the PCR mastermix [16]. Also as the level of Salmonella contamination in food or water samples may be very low, pre-enrichment step may be useful to enhance the detection limit by allowing multiplication of targeted bacterial cell $[50,51]$. Pre-enrichment steps before detection with real-time PCR have increased detection sensitivities by 10 to 1000 fold [52].

Rapid methods to detect the presence of Salmonella are crucial to safeguard public safety. The development of gyrB gene markers provides a rapid and promising technique to quantify bacterial concentration initially present in samples. Increased diagnostic sensitivity and quantitative measurement provided by quantitative PCR methods will enable pathogen dose-response relationships to be determined for risk assessment and future standards setting for Salmonella in water environments and food products [53, 54].

\section{ACKNOWLEDGEMENTS}

We thank Dr Thomas Christopher Hill and Dr Helen Billman-Jacobe for their advice and assistance.

\section{REFERENCES}

[1] Grimont PA, Weill F-X. Antigenic formulae of the Salmonella serovars. WHO Collaborating Centre for Reference and Research on Salmonella, Institut Pasteur, Paris, France 2007.

[2] Helms M, Vastrup P, Gerner-Smidt P, Evans S. Short and long term mortality associated with foodborne bacterial gastrointestinal infections: registry based study Commentary: matched cohorts can be useful. BMJ 2003; 326(7385): 357. http://dx.doi.org/10.1136/bmj.326.7385.357

[3] Angulo FJ, Kirk MD, McKay I, Hall GV, Dalton CB, Stafford $\mathrm{R}$, et al. Foodborne disease in Australia: the OzFoodNet experience. Clin Infect Dis 2008; 47(3): 392-400. http://dx.doi.org/10.1086/589861

[4] iClimate. Waterborne Disease. http://climate.adfi.usq.edu.au/ 75/\#. (accessed September 20, 2012).

[5] Dale K, Kirk M, Sinclair M, Hall R, Leder K. Reported waterborne outbreaks of gastrointestinal disease in Australia are predominantly associated with recreational exposure. Aust N Z J Public Health 2010; 34(5): 527-30. http://dx.doi.org/10.1111/j.1753-6405.2010.00602.x

[6] Lemarchand K, Masson L, Brousseau R. Molecular biology and DNA microarray technology for microbial quality monitoring of water. Crit Rev Microbiol 2004; 30(3): 145-72. http://dx.doi.org/10.1080/10408410490435142

[7] Morgan FU, Pallant L, Dwyer B, Forbes D, Rich G, Thompson R. Comparison of PCR and microscopy for detection of Cryptosporidium parvum in human fecal specimens: clinical trial. J Clin Microbiol 1998; 36(4): 995-8.

[8] Rompré A, Servais $P$, Baudart J, de-Roubin M-R, Laurent $P$. Detection and enumeration of coliforms in drinking water: current methods and emerging approaches. J Microbiol Methods 2002; 49(1): 31-54.

http://dx.doi.org/10.1016/S0167-7012(01)00351-7

[9] Colwell RR, Grimes DJ. Nonculturable microorganisms in the environment: ASM Press 2000. http://dx.doi.org/10.1007/978-1-4757-0271-2

[10] Huq A, Colwell RR. A microbiological paradox: viable but nonculturable bacteria with special reference to Vibrio cholerae. J Food Protection® 1996; 59(1): 96-101.

[11] Muyzer G, Smalla K. Application of denaturing gradient gel electrophoresis (DGGE) and temperature gradient gel electrophoresis (TGGE) in microbial ecology. Antonie Van Leeuwenhoek 1998; 73(1): 127-41.

http://dx.doi.org/10.1023/A:1000669317571

[12] Foy CA, Parkes HC. Emerging homogeneous DNA-based technologies in the clinical laboratory. Clin Chem 2001; 47(6): 990-1000.

[13] Kwang J, Littledike E, Keen J. Use of the polymerase chain reaction for Salmonella detection. Lett Appl Microbiol 1996; 22(1): 46-51.

http://dx.doi.org/10.1111/j.1472-765X.1996.tb01106.x

[14] Rahn K, De Grandis S, Clarke R, McEwen S, Galan J, Ginocchio $C$, et al. Amplification of an invA gene sequence of Salmonella typhimurium by polymerase chain reaction as a specific method of detection of Salmonella. Mol Cell Probes 1992; 6(4): 271-9. http://dx.doi.org/10.1016/0890-8508(92)90002-F

[15] Widjojoatmodjo M, Fluit A, Torensma R, Keller B, Verhoef J. Evaluation of the Magnetic Immuno PCR assay for rapid detection of Salmonella. Eur J Clin Microbiol Infect Dis 1991; 10(11): 935-8.

http://dx.doi.org/10.1007/BF02005447

[16] Malorny B, Hoorfar J, Bunge C, Helmuth R. Multicenter validation of the analytical accuracy of Salmonella PCR: towards an international standard. Appl Environ Microbiol 2003; 69(1): 290-6.

http://dx.doi.org/10.1128/AEM.69.1.290-296.2003

[17] Vantarakis A, Komninou G, Venieri D, Papapetropoulou M. Development of a multiplex PCR detection of Salmonella spp. and Shigella spp. in mussels. Lett Appl Microbiol 2000; 31(2): 105-9.

http://dx.doi.org/10.1046/j.1365-2672.2000.00797.x

[18] Nam H-M, Srinivasan V, Gillespie BE, Murinda SE, Oliver SP. Application of SYBR green real-time PCR assay for 
specific detection of Salmonella spp. in dairy farm environmental samples. Int J Food Microbiol 2005; 102(2): 161-71.

http://dx.doi.org/10.1016/j.ijfoodmicro.2004.12.020

[19] Fey A, Eichler S, Flavier S, Christen R, Höfle MG, Guzmán $\mathrm{CA}$. Establishment of a real-time PCR-based approach for accurate quantification of bacterial RNA targets in water, using Salmonella as a model organism. Appl Environ Microbiol 2004; 70(6): 3618-23.

http://dx.doi.org/10.1128/AEM.70.6.3618-3623.2004

[20] Fukushima M, Kakinuma K, Kawaguchi R. Phylogenetic analysis of Salmonella, Shigella, and Escherichia coli strains on the basis of the gyrB gene sequence. J Clin Microbiol 2002; 40(8): 2779-85.

http://dx.doi.org/10.1128/JCM.40.8.2779-2785.2002

[21] Kakinuma K, Fukushima M, Kawaguchi R. Detection and identification of Escherichia coli, Shigella, and Salmonella by microarrays using the gyrB gene. Biotechnol Bioeng 2003; 83(6): $721-8$

http://dx.doi.org/10.1002/bit.10709

[22] Yamamoto S, Harayama S. PCR amplification and direct sequencing of gyrB genes with universal primers and their application to the detection and taxonomic analysis of Pseudomonas putida strains. Appl Environ Microbiol 1995; 61(3): 1104-9.

[23] Watt PM, Hickson ID. Structure and function of type II DNA topoisomerases. Biochem J 1994; 303(Pt 3): 681.

[24] Wang JC. DNA topoisomerases. Annu Rev Biochem 1996; 65(1): 635-92.

http://dx.doi.org/10.1146/annurev.bi.65.070196.003223

[25] Chang HR, Loo L, Jeyaseelan K, Earnest L, Stackebrandt E. Phylogenetic relationships of Salmonella typhi and Salmonella typhimurium based on 16S rRNA sequence analysis. Int J Syst Bacteriol 1997; 47(4): 1253-4. http://dx.doi.org/10.1099/00207713-47-4-1253

[26] Wang R-F, Cao W-W, Cerniglia CE. Phylogenetic analysis and identification of Shigella spp. by molecular probes. Mol Cell Probes 1997; 11(6): 427-32.

http://dx.doi.org/10.1006/mcpr.1997.0136

[27] Yamamoto S, Harayama S. Phylogenetic analysis of Acinetobacter strains based on the nucleotide sequences of gyrB genes and on the amino acid sequences of their products. Int J Syst Bacteriol 1996; 46(2): 506-11. http://dx.doi.org/10.1099/00207713-46-2-506

[28] Cilia V, Lafay B, Christen R. Sequence heterogeneities among $16 \mathrm{~S}$ ribosomal RNA sequences, and their effect on phylogenetic analyses at the species level. Mol Biol Evol 1996; 13(3): 451-61.

http://dx.doi.org/10.1093/oxfordjournals.molbev.a025606

[29] McClelland M, Sanderson KE, Spieth J, Clifton SW, Latreille $\mathrm{P}$, Courtney $\mathrm{L}$, et al. Complete genome sequence of Salmonella enterica serovar Typhimurium LT2. Nature 2001; 413(6858): 852-6. http://dx.doi.org/10.1038/35101614

[30] Rasmussen R. Quantification on the Light Cycler. Rapid cycle real-time PCR: Springer 2001; pp. 21-34. http://dx.doi.org/10.1007/978-3-642-59524-0 3

[31] Hussain MA, Ford R, Hill J. Determination of fecal contamination indicator sterols in an Australian water supply system. Environmental monitoring and assessment. 2010; 165(1-4): 147-57.

http://dx.doi.org/10.1007/s10661-009-0934-5

[32] Ford R, Hill J, Malik A, English J, Leo A, Kibria G. A pilot study of microbial pathogen monitoring in the central G-MW water supply system: Final report 2008; ISBN: 1-87635-6073.

[33] Trevanich S, Tiyapongpattana S, Miyamoto T. Application of an optimized 18-h method involving one step culturing and single primer-based PCR assay for detection of Salmonella spp. in foods. Food Control 2010; 21(5): 593-8.

http://dx.doi.org/10.1016/j.foodcont.2009.08.012

[34] Cheung P-Y, Kam KM. Salmonella in food surveillance: PCR, immunoassays, and other rapid detection and quantification methods. Food Res Int 2012; 45(2): 802-8. http://dx.doi.org/10.1016/j.foodres.2011.12.001

[35] Centers for Disease Control and Prevention. Salmonella surveillance: Annual summary, 2004. Atlanta, Georgia: US Department of Health and Human Services, CDC 2005.

[36] Centers for Disease Control and Prevention. Surveillance for foodborne disease outbreaks - United States, 2006. Morbidity and Mortality weekly Report 2009; 58(22): 609-15.

[37] New Zealand Food Administration Manual. 1995 Microbiolgical Reference Criteria for Food [Report on the internet]. [cited 2012 Sept 23]: Available from: http://www.foodsafety.govt.nz/elibrary/industry/microbiologica I_reference-guide_assess.pdf

[38] Covert TC, Meckes MC. Description of the agent. Waterborne Pathogens 2006; 135.

[39] Hussong D, Enkiri NK, Burge WD. Modified agar medium for detection of Salmonella in composted biosolids. Water Res 1984; 31: 2664-67.

[40] Novinscak A, Surette C, Filion M. Quantification of Salmonella spp. in composted biosolids using a TaqMan qPCR assay. J Microbiol Methods 2007; 70(1): 119-26. http://dx.doi.org/10.1016/j.mimet.2007.03.019

[41] Moganedi K, Goyvaerts E, Venter SN, Sibara M Optimisation of the PCR-invA primers for the detection of Salmonella in drinking and surface waters following a precultivation step. Water Sa 2007; 33(2).

[42] Hughes D, Dailianis AE, Hill L, Mclntyre DA, Anderson A. TECRA Unique Test for rapid detection of Salmonella in food: collaborative study. J AOAC Int 2001; 84(2): 416-29.

[43] Hanai K, Satake M, Nakanishi H, Venkateswaran K. Comparison of commercially available kits with standard methods for detection of Salmonella strains in foods. Appl Environ Microbiol 1997; 63(2): 775-8.

[44] Cheung PY, Kwok K, Kam K. Application of BAX system, Tecra UniqueTM Salmonella test, and a conventional culture method for the detection of Salmonella in ready-to-eat and raw foods. J Appl Microbiol 2007; 103(1): 219-27. http://dx.doi.org/10.1111/j.1365-2672.2006.03210.x

[45] Ishii K, Fukui M. Optimization of annealing temperature to reduce bias caused by a primer mismatch in multitemplate PCR. Appl Environ Microbiol 2001; 67(8): 3753-5. http://dx.doi.org/10.1128/AEM.67.8.3753-3755.2001

[46] LaMontagne M, Michel Jr F, Holden P, Reddy C. Evaluation of extraction and purification methods for obtaining PCRamplifiable DNA from compost for microbial community analysis. J Microbiol Methods 2002; 49(3): 255-64. http://dx.doi.org/10.1016/S0167-7012(01)00377-3

[47] Yamada S, Ohashi E, Agata N, Venkateswaran K. Cloning and nucleotide sequence analysis of gyrB of Bacillus cereus, $B$. thuringiensis, $B$. mycoides, and $B$. anthracis and their application to the detection of $B$. cereus in rice. Appl Environ Microbiol 1999; 65(4): 1483-90.

[48] Behets J, Declerck P, Delaedt Y, Verelst L, Ollevier F. A duplex real-time PCR assay for the quantitative detection of Naegleria fowleri in water samples. Water Res 2007; 41(1): 118-26.

http://dx.doi.org/10.1016/j.watres.2006.10.003

[49] Klerks $M$, Van Bruggen A, Zijlstra C, Donnikov M. Comparison of methods of extracting Salmonella enterica serovar enteritidis DNA from environmental substrates and quantification of organisms by using a general internal procedural control. Appl Environ Microbiol 2006; 72(6): 387986.

http://dx.doi.org/10.1128/AEM.02266-05 
[50] Liming $\mathrm{SH}$, Bhagwat AA. Application of a molecular beacon-real-time PCR technology to detect Salmonella species contaminating fruits and vegetables. Int $\mathrm{J}$ Food Microbiol 2004; 95(2): 177-87.

http://dx.doi.org/10.1016/j.ijfoodmicro.2004.02.013

[51] Kumar R, Surendran P, Thampuran N. Rapid quantification of Salmonella in seafood using real-time PCR assay. J Microbiol Biotech 2010; 20(3): 569-73.

[52] Gorski L, Liang AS. Effect of enrichment medium on real-time detection of Salmonella enterica from lettuce and tomato enrichment cultures. J Food Prot 2010; 73(6): 1047-56.
[53] Donovan E, Unice K, Roberts JD, Harris M, Finley B. Risk of gastrointestinal disease associated with exposure to pathogens in the water of the Lower Passaic River. Appl Environ Microbiol 2008; 74(4): 994-1003.

http://dx.doi.org/10.1128/AEM.00601-07

[54] Schets F, Van Wijnen J, Schijven J, Schoon H, de Roda Husman A. Monitoring of waterborne pathogens in surface waters in Amsterdam, The Netherlands, and the potential health risk associated with exposure to Cryptosporidium and Giardia in these waters. Appl Environ Microbiol 2008; 74(7): 2069-78.

http://dx.doi.org/10.1128/AEM.01609-07

Received on 27-09-2013

Published on 30-11-2013

\section{DOI: http://dx.doi.org/10.12970/2311-1755.2013.01.01.4}

(C) 2013 Leo et al.; Licensee Synergy Publishers.

This is an open access article licensed under the terms of the Creative Commons Attribution Non-Commercial License (http://creativecommons.org/licenses/by-nc/3.0/) which permits unrestricted, non-commercial use, distribution and reproduction in any medium, provided the work is properly cited. 